\title{
THE CZECH REPUBLIC SUGAR MARKET DEVELOPMENT IN THE CONTEXT OF THE PHASING OUT OF SUGAR QUOTA
}

\author{
Kateřina KOVÁŘOVÁa ${ }^{\mathrm{a}}$, Martin NÁDENÍK ${ }^{\mathrm{b}}$, Kamil PÍCHA ${ }^{\mathrm{c}}$ \\ a Jan Evangelista Purkyně University, Faculty of Social and Economic Studies, Moskevská 54, Ústí nad \\ Labem, Czech Republic, phone : +420 475284 709, email: katerina.kovarova@ujep.cz \\ ${ }^{\mathrm{b}}$ University of Life Science in Prague, Faculty of Economics and Management \\ ${ }^{c}$ University of South Bohemia, Faculty of Economics, Studentská 13, 37005 České Budějovice, Czech \\ Republic, e-mail: kpicha@ef.jcu.cz
}

Cite this article: Kovářová, K., Nádeník, M., Pícha, K. (2017). The Czech Republic Sugar Market Development in the Context of the Phasing out of Sugar Quota. Deturope, 9, 2: 110-117.

\begin{abstract}
The aim of the paper is to assess the current position and situation of the Czech sugar market actors. The new situation is expected due to the declared phasing of out of sugar quota with the EU Common Agriculture Policy. The analysis is based on secondary date from the statistics of the Czech Statistical Office and the Ministry of Agriculture of the Czech Republic. Czech Republic has a long strong tradition in sugar production. It lost a leading position in the sugar market in the past. The sugar industry has been affected by various factors during several periods. The last big challenge for the market was the restricting system of the Common Agriculture Policy of the European Union. The expected development of the sugar market in the no-quota environment could be a good opportunity for both Czech sugar beet producers and sugar beet manufacturers (sugar producers).
\end{abstract}

Keywords: sugar quota abolishment, market, sugar beet, European Union

\section{INTRODUCTION}

Quota limits on sugar production, defined at EU Member State level and further allocated over processing factories and individual sugar beet growers, have been in place since 1960s. The European agricultural market has been criticized for its heavy regulations and subsidization. The sugar market is one of the most regulated ones (Benešová, Řezbová, Smutka, \& Laputková, 2015). One result of this policy was that the EU had been both the second largest importer and second largest exporter in the world market (Moyo, \& Spreen, 2011). On the other hand, the impact of the EU Common Agriculture Policy (CAP) on the food prices has gradually weakened (Swinnen, Knops, \& van Herck, 2015). It relates with several reasons, next to the other factors of world agriculture and world market development, we have also to admit that the CAP changed their priorities and concepts. The most important seems to be a change in the direct payment character as to their separation from production ("decoupling"), so that such payments would be conditional on the fulfillment of many 
standards relating to environmental protection, animal welfare, food safety and food quality (Bečvářová, 2011).

The Czech sugar industry was influenced by a dramatic transition process, which was accompanied by many changes as for example: Many sugar factories reduced their production, or closed down completely; there were changes of ownership and increased role of foreign (often unpredictable) investors, modifications of sugar distribution nets and technological innovations (Krejčí, Havlíček, Klusáček, and Martinát, 2014).

In 2006, a reform of the Common Agricultural Policy (CAP) sugar regime brought a simplification of the quota structure, and incentives were offered to Member States that opted to reduce - or renounce altogether - their national quota limits. Quotas were prolonged until 2014/15, with no commitment to further renewal. Actually, they were finally prolonged till the end of 2016/2017 to be definitely abolished by 30th September 2017. The basic aim of Sugar reforms, which was submitted to the EU Commission and has been approved by the Council of Ministers in November 2005, was to minimize the price and production of sugar, mainly at the expense of the least competitive growers and sugar areas, increase the competitiveness and to make the European market more accessible for developing countries (Krouský, 2008).

In general terms, the EU CAP sugar regime led to an oligopolistic market situation in the European Union. Current EU sugar production is concentrated in five countries (France, Germany, Poland, Great Britain and Netherlands. Some countries discontinued sugar production (Portugal, Ireland, Latvia, Bulgaria and Slovenia). Other countries (including the Czech Republic) reduced the production (Baudisová, 2017). Majority of sugar quotas are controlled by companies headquartered in Germany, France, the Netherlands and the United Kingdom. In nowadays - the sugar quota system in the European Union is operated/controlled by only a few very powerful operators: Südzucker, Nordzucker, Tereos, ABF, Pfeifer \& Langen, Royal Cosun and Cristal Union (Řezbová, Maitah, \& Sergienko, 2015). Sugar in the EU has been one of the most heavily subsidized sectors (Gotor, \& Tsigas, 2011).

The basic change in the sugar market from 1st October 2017 is then the end of production quotas, which was for the Czech Republic 372,459.207 t of sugar - divided among five sugar companies. The 1st October means the beginning of the period of unregulated sugar production in the EU as well as of the export of sugar to third countries. Sugar factories will no longer pay production batch of sugar (EUR 12/t) and fixed minimum sugar beet price (EUR 26.29/t) ceases to apply, by means of which the grower has so far been "protected". Also the over-quota sugar mode ends. This system set out how to deal with the "excess" 
sugar. With regard to the export of sugar to third countries, quantitative restrictions on exports of the over-quota sugar ceases to apply. Other international agreements will not change and will continue to be in force.

System of the market order through production quotas has ensured a balance of supply and demand, so that there were no stronger price fluctuations. For many reasons a decrease of sugar prices should be expected (Burrell, Himics, Van Doorslaer, Ciaian, \& Shrestha, 2014). . The reasons for the decline in sugar prices are, however, more numerous. In addition to the quota abolishing, there are excellent sugar beet yields in the zone of Central Europe and the high increase in some areas of growing countries. The price is, of course influenced also by the world price for sugar (Smutka, Rumánková, Pulkrábek, \& Benešová, 2013). Further development of the EU sugar market depends also on behaviour of sugar producers from out of the European Union who have made imports thanks to the preferential access to the EU market (Meyer et al., 2016).

Another question is the link of growing sugar beet and the topical problems of sustainable development. Sustainability concerns have a fundamental economic aspect regarding competitiveness with cane sugar (Ǩezbová, Maitah, \& Sergienko, 2015) and an environmental aspect including mainly the current issue of emissions and foreign chemical substances (Chochola, Pulkrábek, 2012).

The aim of the paper is to assess the current position and situation of the Czech sugar market actors.

\section{METHODS}

Secondary data were collected from the statistics of the Czech Statistical Office and the Ministry of Agriculture of the Czech Republic. Data were projected by means of Microsoft Excel.

In order to project the development trend, the polynomial function was imployed, as follows:

$$
f: y=a_{n} n^{n}+a_{n-1} x^{n-1}+\ldots+a_{2} x^{2}+a_{1} x+a_{0}
$$

where $a_{n}, a_{n-1}, \ldots, a_{2}, a_{1}, a_{0} \in R, a_{n} \neq 0$, are real cofficients

$a_{n}=$ coefficient of degree $n$ (for the highest square number),

$a_{k}=$ coefficient of degree $k$,

$a_{1}=$ coefficient of linear term, $a_{1} x$ linear term,

$\mathrm{a}_{0}=$ absolute term. 


\section{RESULTS}

The total volume of the processed sugar beet has increased in long term. After a several-years decrease in the early period of applying the Common Market Organization (CMO) in the Czech Republic (since 2000), the sugar beet production and procession regained and later even surpassed their previous quantities. The biggest quantity jump has come in 2011/2012, when the year-on-year increase of the quantity was 656,790 tons of the processed sugar beet, i.e $22.5 \%$. Not only in case of the sugar beet production but even the sugar production achieved the best results in previous history of the Czech Republic (Froněk, Trnková, \& Hanák, 2012). The overall increasing trend since 2008 was confirmed by the polynomial regression (see Fig. 1). The value of the regression coefficient (coefficient of determination) is high and the test was significant.

Figure 1 Evolution of the volume of processed sugar beet

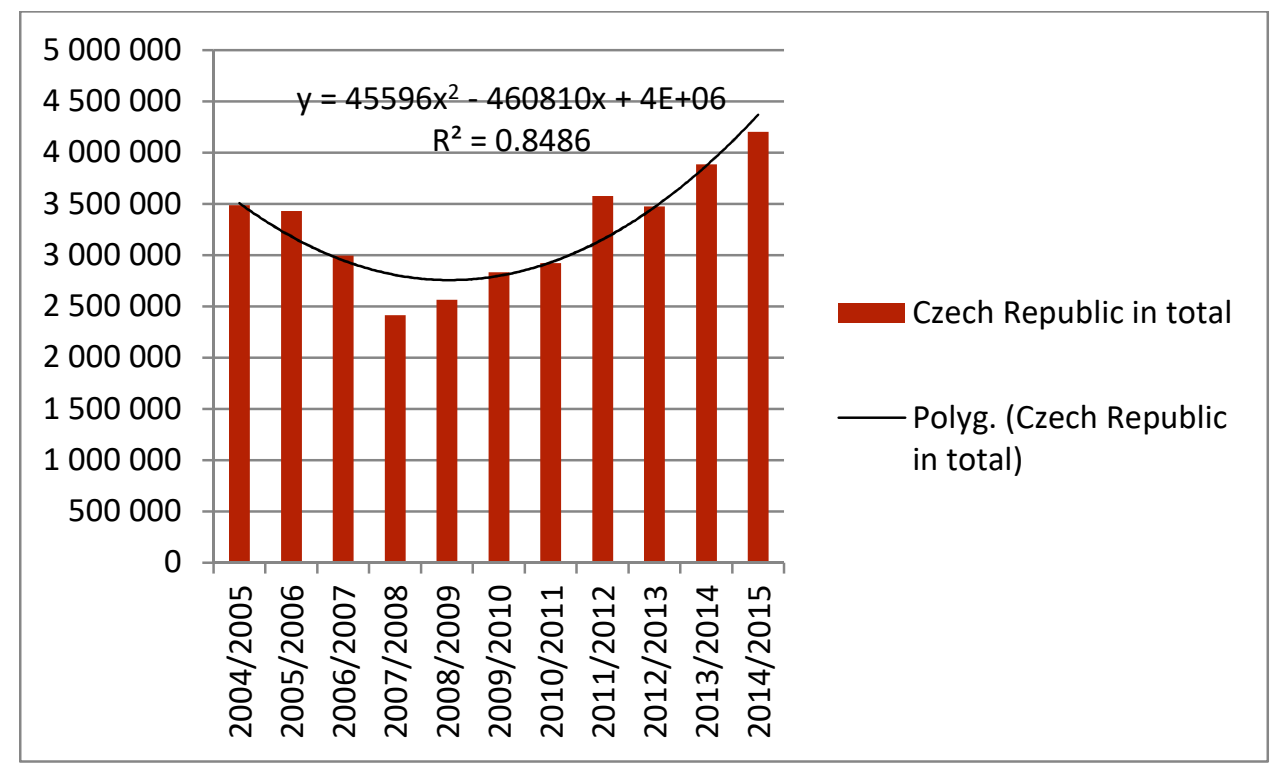

Variability in the volume of processed sugar beet is significantly $(84.86 \%)$ explained by the evolution in time. This was achieved after the removal of significant outlying value in 2015/2016, where there was an important decrease in harvest areas and at the same time a significant decrease of the yield was recorded (see table). The yield was affected by significantly higher temperatures against the long-term normal (Gebler \& Kožnarová, 2016). The range of harvest area is in the plans for the following years returning to the previous level. Beets are currently grown exclusively in the areas where they thrive. Both the yields and the sugar content are growing in the long term and are on a comparable level with the developed European countries (Reinbergr, 2017). The development of the volume of 
processed sugar beet corresponds with the statistics on the yield (quantity of harvested tubers, Tab. 1) and the harvested area (Tab. 2).

Table 1 Yield of tubers

\begin{tabular}{|c|c|c|c|c|c|c|c|}
\hline Campaign & $2004 / 2005$ & $2005 / 2006$ & $2006 / 2007$ & $2007 / 2008$ & $2008 / 2009$ & $2009 / 2010$ & $2010 / 2011$ \\
\hline $\begin{array}{l}\text { Yield } \\
\text { (t/ha) }\end{array}$ & 50.57 & 54.31 & 53.64 & 54.71 & 58.31 & 60.94 & 59.34 \\
\hline Campaign & $2011 / 2012$ & $2012 / 2013$ & $2013 / 2014$ & $2014 / 2015$ & $2015 / 2016$ & $2016 / 2017$ & \\
\hline $\begin{array}{l}\text { Yield } \\
\text { (t/ha) }\end{array}$ & 71.26 & 67.16 & 62.79 & 78.11 & 60.94 & 71.23 & \\
\hline
\end{tabular}

Source: Statistika komodity cukr - cukrová řepa v České republice. 2016 Retrieved from http://www.cukrlisty.cz/dokumenty/mze/statistika-CZ-01112016.pdf

Table 2 Harvested area

\begin{tabular}{|l|l|l|l|l|l|l|l|}
\hline Campaign & $2004 / 2005$ & $2005 / 2006$ & $2006 / 2007$ & $2007 / 2008$ & $2008 / 2009$ & $2009 / 2010$ & $2010 / 2011$ \\
\hline Area (ha) & 68970 & 63170 & 55801 & 44137 & 43987 & 46472 & 49257 \\
\hline Campaign & $2011 / 2012$ & $2012 / 2013$ & $2013 / 2014$ & $2014 / 2015$ & $2015 / 2016$ & $2016 / 2017$ & \\
\cline { 1 - 5 } Area (ha) & 50184 & 51727 & 52691 & 53771 & 44978 & 52340 & \\
\cline { 1 - 3 } & & &
\end{tabular}

Source: Statistika komodity cukr - cukrová řepa v České republice. 2016 Retrieved from http://www.cukrlisty.cz/dokumenty/mze/statistika-CZ-01112016.pdf

Production of sugar constantly overpasses the needs of the country. Czech Republic is selfsufficient in this commodity and export sugar to other countries (as implied from the Tab. 1, 2 and 3).

Table 3 Country's consumption:

\begin{tabular}{|c|c|c|c|c|c|c|c|}
\hline Year & $2004 / 2005$ & $2005 / 2006$ & $2006 / 2007$ & $2007 / 2008$ & $2008 / 2009$ & $2009 / 2010$ & $2010 / 2011$ \\
\hline $\begin{array}{l}\text { Consumption } \\
(1,000 t)\end{array}$ & 336,3 & 451,8 & 514,0 & 395,5 & 351,3 & 393,1 & 437,1 \\
\hline Year & $2011 / 2012$ & $2012 / 2013$ & $2013 / 2014$ & $2014 / 2015$ & $2015 / 2016$ & $2016 / 2017$ & \\
\hline $\begin{array}{l}\text { Consumption } \\
(1,000 t)\end{array}$ & 497,9 & 518,8 & 418,2 & 437,9 & 416,2 & & \\
\hline
\end{tabular}

Source: Froněk, D. Trnková, J. and Hanák, J. (2012), Froněk, D. Trnková, J., Hanák, J. (2016), Adamec, R., Froněk, D. (2010).

Thanks to the fact that countries such as Hungary, Slovakia, Romania or Ukraine will be very probably in sugar production deficit even in future, Czech producers could look out for a very interesting market in the region of Central and Eastern Europe with up to 70 million potential customers. The undoubted advantage of the Czech Republic is also a greater distance from the sea that protects it from imports of white sugar and as well as from imports of raw sugar for further refining. The latter imports, indeed, are likely to be economically disadvantageous due to the proximity of raw and white sugar prices overall (Reinbergr 2017). 
Table 4 Development of average consumer prices of crystal sugar (CZK)

\begin{tabular}{|c|c|c|c|c|c|c|c|c|c|c|c|}
\hline $\begin{array}{l}2^{\text {nd }} \\
\text { week }\end{array}$ & $\begin{array}{l}7^{\text {th }} \\
\text { week }\end{array}$ & $\begin{array}{l}11^{\text {th }} \\
\text { week }\end{array}$ & $\begin{array}{l}15^{\text {th }} \\
\text { week }\end{array}$ & $\begin{array}{l}19^{\text {th }} \\
\text { week }\end{array}$ & $\begin{array}{l}24^{\text {th }} \\
\text { week }\end{array}$ & $\begin{array}{l}28^{\text {th }} \\
\text { week }\end{array}$ & $\begin{array}{l}32^{\text {th }} \\
\text { week }\end{array}$ & $\begin{array}{l}37^{\text {th }} \\
\text { week }\end{array}$ & $\begin{array}{l}41^{s t} \\
\text { week }\end{array}$ & $\begin{array}{l}46^{\text {th }} \\
\text { week }\end{array}$ & $\begin{array}{l}50^{\text {th }} \\
\text { week }\end{array}$ \\
\hline 201615.66 & 15.62 & 16.06 & 16.48 & 16.64 & 16.72 & 17.86 & 18.23 & 18.70 & 19.32 & 19.42 & 20.34 \\
\hline 201519.46 & 20.12 & 19.36 & 19.49 & 19.09 & 17.45 & 17.48 & 17.62 & 16.65 & 16.04 & 15.17 & 15.64 \\
\hline 201424.27 & 24.02 & 23.90 & 23.09 & 23.29 & 22.63 & 21.72 & 21.62 & 20.97 & 19.67 & 19.72 & 19.40 \\
\hline
\end{tabular}

Table 5 Development of average prices of producers of granulated sugar (CZK)

\begin{tabular}{|r|c|c|c|c|c|c|}
\hline & January & February & March & April & May & June \\
\hline 2016 & 12,46 & 12,40 & 12,31 & 12,35 & 12,35 & 12,30 \\
\hline 2015 & 12,74 & 12,43 & 12,29 & 12,02 & 12,01 & 12,01 \\
\hline 2014 & 17,29 & 17,10 & 17,01 & 16,49 & 15,91 & 15,98 \\
\hline & July & August & September & October & November & December \\
\hline 2016 & 12,36 & 12,36 & 12,52 & 12,83 & 13,13 & 13,08 \\
\hline 2015 & 11,88 & 11,87 & 11,81 & 11,95 & 12,18 & 12,35 \\
\hline 2014 & 15,51 & 15,31 & 15,31 & 14,66 & 13,70 & 13,13 \\
\hline
\end{tabular}

Source of data: Czech statistical office - https://www.czso.cz/csu/czso/setreni-prumernych-cen-vybranychvyrobku-potravinarske-vyrobky-casove-rady

\section{DISCUSSION}

The growth (or regrowth) of the harvest area in the Czech Republic since 2009, hand in hand with the improving yield could promise a good potential of Czech producers for exporting sugar (seeing the fact the consumption of the domestic market is surpassed by the production. A question remained, what will be the evolution of the market after the EU quota abolition. If we would look for a parallel, we can see the situation after the recent milk quota abolition, even though the particular factors should not be absolutely the same (Kovárová and Procházková, 2017). There was a slight price reduction as expected by OECD and FAO (2014). However, the effect of the no-quota environment was not very visible in the context of influence of other factors of the dairy market (Salou et al., 2017).

A very few studies (compared to the studies preceding the phasing out of dairy quotas) have been devoted to the scenarios of the sugar market development after phasing out of sugar quotas. OECD-FAO Agricultural Outlook 2014 has predicted the possible development if both situations - the quotas will continue and the quota will be removed. In case of the sugar quota abolishing the sugar beet production is expected to rise as well as the production of isoglucose. The processing of the sugar beet for sugar is expected to increase at the expense of the ethanol production. The price could slightly decrease, but the world price would remain strongly volatile. A lower price of sugar could lead producers using sweeteners to switch from 
other sweeteners to sugar. Lower price of sugar could also lead to the decrease of sugar import to the EU, as it would be no more cost-effective for cane sugar producers.

\section{CONCLUSION}

In the no-quota environment, sugar beet producers get a good opportunity to raise their production. Sugar beet manufacturers will be to consider their focus on sugar and/or ethanol production. Sugar production still seems to be more profitable than ethanol, so that with no limits to sugar production and a potential to market it the choice for sugar production could be expected. However, Czech sugar beet manufacturers have recently invested into the ethanol production technology. Namely in the periods of lower prices of sugar, there is a good potential to export sugar to our European countries who are not self-sufficient in the sugar production.

\section{REFERENCES}

Adamec, R., \& Froněk, D. (2010). Situační a výhledová zpráva cukr a cukrová řepa květen 2010. Ministerstvo zemědělství.

Baudisová, H. (2017). Informace ze sektoru cukrové řepy. Zemédělec, 30:12

Bečvářová, V. (2011). Economic and regional consequences of direct payments under the current CAP philosophy. Acta univ. agric. et silvic. Mendel. Brun., 59(4), 19-26

Benešová, I., Řezbová, H., Smutka, L., \& Laputková, A. (2015). European Sugar MarketImpact of Quota System. Acta univ. agric. et silvic. Mendel. Brun., 63(6), 1825-1838.

Burrell, A., Himics, M., Van Doorslaer, B., Ciaian, P., \& Shrestha, S. (2014). EU sugar policy: A sweet transition after 2015? EUR-OP.

Chochola, J., \& Pulkrábek, J. (2012). Sugar Beet Research in the World, Listy cukrovarnické a reparské, 128(5-6), 177-179

Froněk, D., Trnková, J., \& Hanák, J. (2012). Situační a výhledová zpráva cukr a cukrová repa, ř́jen 2012. Ministerstvo zemědělství,

Froněk, D., Trnková, J., \& Hanák, J. (2016). Situační a výhledová zpráva cukr a cukrová repa, červen 2016. Ministerstvo zemědělství, ISBN 978-80-7343-044-4

Gebler, J., Kožnarová, V., \& Hájková, L. (2016). Zpráva o cukrovarnické kampani 2015/2016 v České republice (Report on Sugar Campaign 2015/2016 in Czech Republic). Listy Cukrovarnické a Řepařské, 132, (7-8), 232-258.

Gotor, E., \& Tsigas, M. E. (2011). The impact of the EU sugar trade reform on poor households in developing countries: A general equilibrium analysis. Journal of Policy Modeling, 33(4), 568-582.

Kovářová, K., \& Procházková, K. (2017). Vliv sezónní dynamiky jakostních ukazatelů na výkupní cenu mléka v kontextu situace na trhu. Deturope, 9, 1: 35-46

Krejčí, T., Havlíček, M., Klusáček, P., \& Martinát, S. (2014). Úvodní poznámky k výzkumu osudu cukrovarnických brownfields v České republice (Introductory Research Notes on Fate of Sugar-Industry-Brownfields in Czech Republic). Listy cukrovarnické a řepařské, 130(12), 406-411. 
Krouský, J. (2008). Restrukturalizace cukrovarnického průmyslu v EU směřuje do finále. Listy Cukrovarnické a Řepařské, 124(3), 70-72

Meyer, F., Traub, L.N., Davids, T., Kirimi, L., Gitau, R., Mpenda, Z., ...Boulanger, P. (2016). Modelling wheat and sugar markets in Eastern and Southern Africa; Regional Network of Agricultural Policy Research Institutes (ReNAPRI)

Moyo, S., \& Spreen, T. H. (2011). An Update on the Consequences of EU Sugar Reform. International Journal on Food System Dynamics, 2(1), 67-76.

OECD and FAO (2014). OECD-FAO Agricultural Outlook 2014. Paris, OECD Publishing (2014). Retrieved from http://www.keepeek.com/Digital-AssetManagement/oecd/agriculture-and-food/oecd-fao-agricultural-outlook2014_agr_outlook-2014-en\#.Wf3i72j9TIU\#page1

Reinbergr, O. (2017) Návrat českého cukrovarnictví do liberálního prostředí. Listy Cukrovarnické a Řepařské 133, č. 5-6, květen-červen 2017, 166-169

Řezbová, H., Maitah, M., \& Sergienko, O. I. (2015). EU quota sugar market concentration the main drivers of EU sugar market. AGRIS on-Line Papers in Economics and Informatics, 7(4), 131-142

Salou, T., van der Werf, H. M., Levert, F., Forslund, A., Hercule, J., \& Le Mouël, C. (2017). Could EU dairy quota removal favour some dairy production systems over others? The case of French dairy production systems. , 153, 1-10.

Smutka, L., Rumánková, L., Pulkrábek, J., \& Benešová, I. (2013). Main Determinants of Supply and Demand on World Sugar Market. Listy Cukrovarnické a Řepařské, 129(4), 142-145.

Swinnen, J., Knops, L., \& van Herck, K. (2015) Food Price Volatility and EU Policies. In Pinstrup-Andersen, P. (Ed.). (2015). Food price policy in an era of market instability: a political economy analysis. UNU-Wider Studies. Oxford: Oxford University Press. Chapter 21, 457-478 